\title{
Habitat Suitability Model of Prehistoric Asian Hippo Hippopotamus sivalensis spp. From The Late Pleistocene of East Java
}

\author{
Andri Wibowo * \\ University of Indonesia (UI), West Java, 16424. Indonesia; andri.wibowo@sc.ui.ac.id \\ * Correspondence email: paleobio2020@gmail.com
}

\begin{abstract}
In the late Pleistocene, a prehistoric hippo species was distributed from Africa to the Asia including Pakistan, India, and Java Island. This study aims to model habitat suitability of Asian hippo known as a Hippopotamus sivalensis spp. in east Java. The measured parameters included the fossil locality, vegetation cover, elevation, and distance to the river in a forest river basin sizing $6652 \mathrm{Ha}$. Those parameters using GIS were weighted, overlaid, and interpolated to determine the most suitable habitats. The model projected that the suitable habitats of $\mathrm{H}$. sivalensis spp. were in the central of the basin near the river. The largest suitable habitats were located in the eastern parts of basin which were dominated by forests.
\end{abstract}

Keywords: elevation; habitat; hippo; Pleistocene; river

\section{Introduction}

Currently in the modern era or also known as Anthropocene, there are only 2 species of hippos. The two species include the common hippopotamus (Hippopotamus amphibius) and the pygmy hippo (Choeropsis liberiensis). H. amphibious lives in East to South Africa, while C. liberiensis lives solitary in the rainforests of West Africa. In fact, mammals, including hippos, existed several millions of years ago. Mammals appeared 35 million years ago along with the existence of plants. The history of the existence of mammals on the island of Java began around 1.5 million years ago. The period of fauna existence itself consists of several periods which include Satir (1.5 million), Cisaat (1.2 million), Trinil (1 million), Kedungbrubus (800 thousand), Ngandong (400 thousand), and Punung (100 thousand). It was during the Punung period that modern mammals emerged, such as elephants, tigers, rhinos, gibbons, orang-utans, deer, and long-tailed monkeys.

The migration of fauna is thought to have come from Siwalik, Narbada, and Burma via the Siva-Malayan route (De Vos 1983, Sondaar 1984, Leinders et al. 1985, Sudijono 1986, Aziz 2000). The migration of fauna was supported by the existence of a route connecting the Asian continent and Java island along with the decline in sea level in the Sunda strait at the beginning of the Pleistocene 2.6 million years ago. The migration of fauna to Java island includes several types. In Cisaat and Trinil, inhabited by Stegodon trigonocephalus who came via the Siva-Malayan route from Siwalik, Narbada, and Burma. Meanwhile, Elephas and Tapirus make up the population of Kedung Brubus and Ngandong. Then in Cisaat and Ngandong, which were inhabited by prehistoric buffalo.

At the end of the Pleistocene, sea levels continued to decline and gave rise to a wider area of land between the Asian continent and Java island. As a result more species are migrating through this corridor. However, during the Holocene era, sea levels rose and fell again and submerged the land between the Asian Continent and the previously formed Java island. This happened about 12 thousand years ago.

In the late Pleistocene, the hippo Hippopotamus sivalensis spp. also includes fauna that migrate to Java. This species is thought to have lived from the oldest Satir to Ngandong periods (400 thousand years ago). Until recently, fossils of Hippopotamus sivalensis spp. have been found in 
various locations in central to east Java. To complement existing data and body of knowledge, a study on habitat modeling of Hippopotamus sivalensis spp. on the island of Java is needed.

\section{Methods}

The study area for habitat suitability modeling was selected in the Kedung Brubus forest river basin located in east Java (Figure 1). The areas of basin were $6652 \mathrm{Ha}$. The elevation of this study area was ranging from $110 \mathrm{~m}$ to the $387 \mathrm{~m}$ especially in the hilly areas in the north. There was a $27.50 \mathrm{~m}$ width river in the middle parts of the forest. The H. sivalensis fossils were excavated in the 2 locations. First location was on the riverbank on the west side of the river. The second location was in the forest on the east side of the forest.

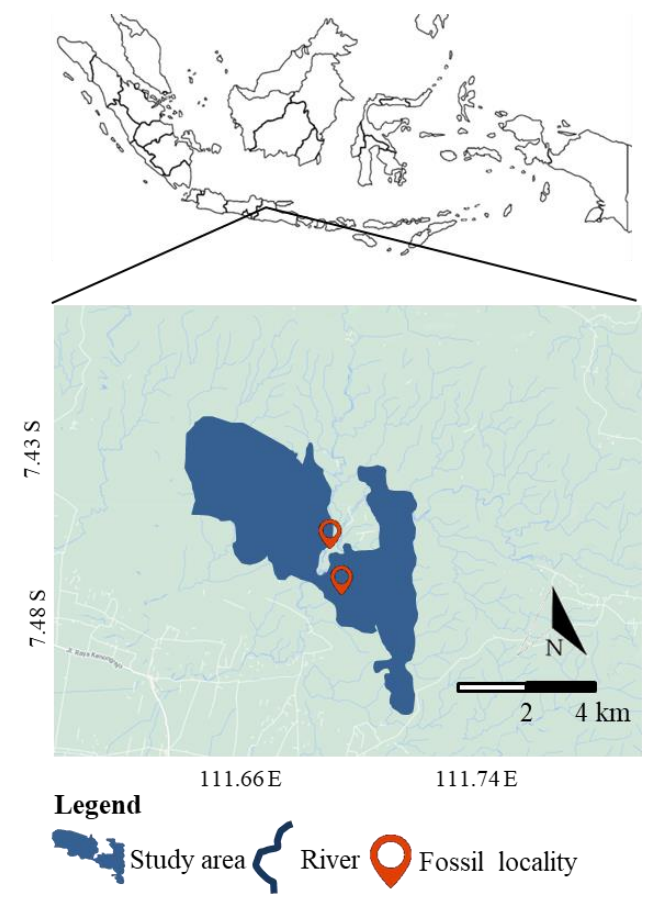

Figure 1. The study area and fossil localities in Kedung Brubus forest river basin, east Java.

Habitat modeling was following method by Wibowo (2020) with some modifications. Previous study was on forest dwelling species while hippos are known preferring aquatic habitat as well. In their habitat, hippos are having micro aquatic habitats including lakes and rivers (Dietz et al 2000, Kanga et al. 2011). According to Wibowo (2020), the habitat modeling was started from classification of vegetation covers from the orthophoto. The photo then classified into vegetation covers included trees, shrubs, and grass. For hippo's habitat suitability, several factors included elevation and distances to the river were also incorporated in to the model (Figure 2). Those determinant factors were weighed, given by scores, overlaid, and interpolated using Geographical Information System following Buruso (2018).
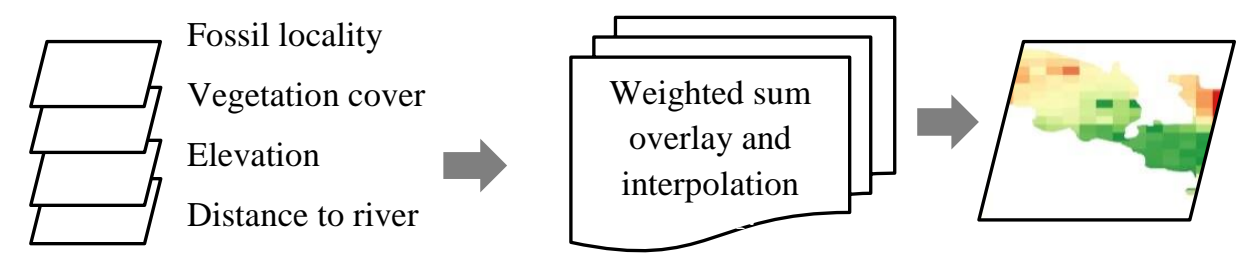

Figure 2. The methods for suitable habitat model development of Hippopotamus sivalensis spp. in Java island in the late Pleistocene. 


\section{Results}

The measured environmental parameters in the Kedung Brubus basin were available in Figure 3. The basin has 2 types of river networks. First type was the small streams with width $<2 \mathrm{~m}$ that were distributed widely across the basin. The western parts of basin have less streams than eastern parts. The large river with width equals to $27.50 \mathrm{~m}$ was located in the central of basin (Figure 3.a).

The elevations of Kedung Brubus were ranging from 110 to $387 \mathrm{~m}$. Most hilly areas were located in the northern parts of basin. The landscape of eastern parts was higher than western parts (Figure 3.b). The vegetation covers in Kedung Brubus were dominated by the trees and bush. The hilly landscapes in north were dominated by bushes. While forests dominated the vegetation covers in southern parts of basin (Figure 3.c). The H. sivalensis spp. fossils were found in the river banks in west and in the forest in east. The elevations where the fossils found were $110 \mathrm{~m}$ for river banks and $150 \mathrm{~m}$ for forest.

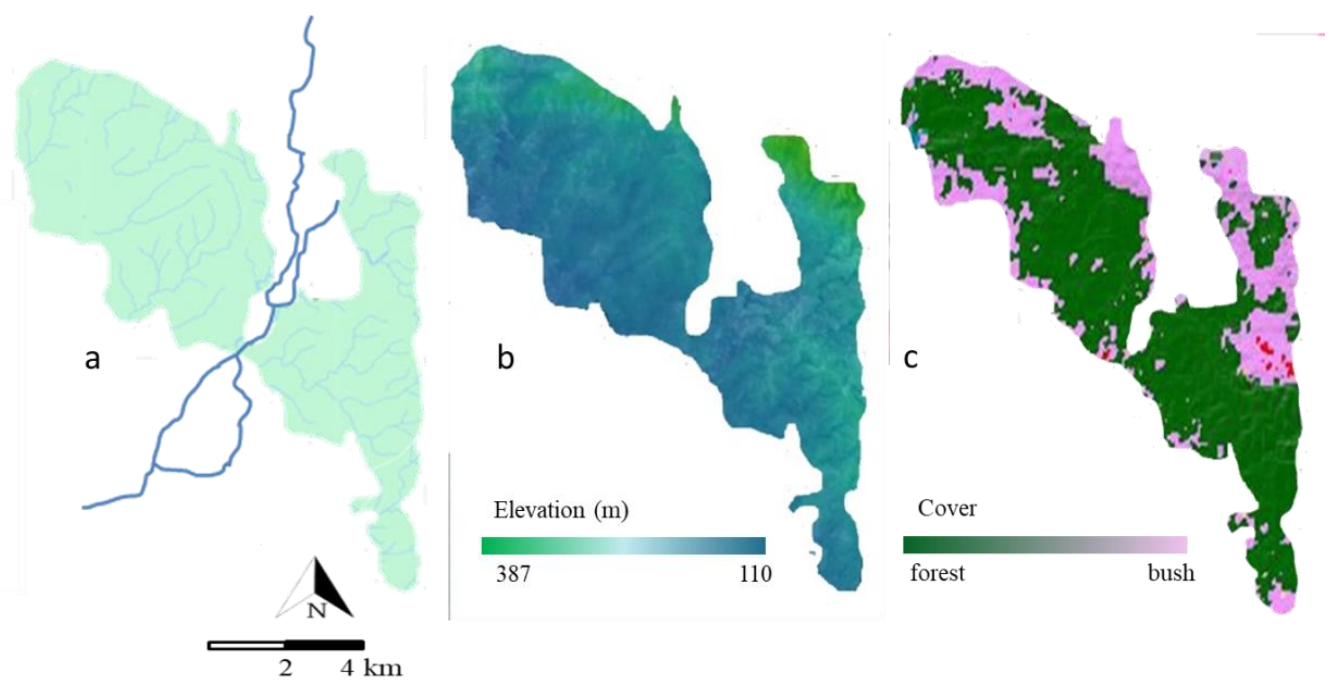

Figure 3. The river networks (a), elevation (b), and vegetation covers in Kedung Brubus forest river basin, east Java in the late Pleistocene.

The Figure 4 presents the habitat suitability of Hippopotamus sivalensis spp. in Kedung Brubus forest river basin, east Java. The suitability model was developed based on the fossil localities and environmental parameters. The model projected and divided the basin based on its suitability into 3 levels include most, moderate, and least suitable. As can be seen from Figure 4 that the most suitable habitats were estimated in the central of the basin near the river. The largest suitable habitats were also located in the eastern parts of basin. Most northern parts of the basin were less suitable in compared to the southern parts.

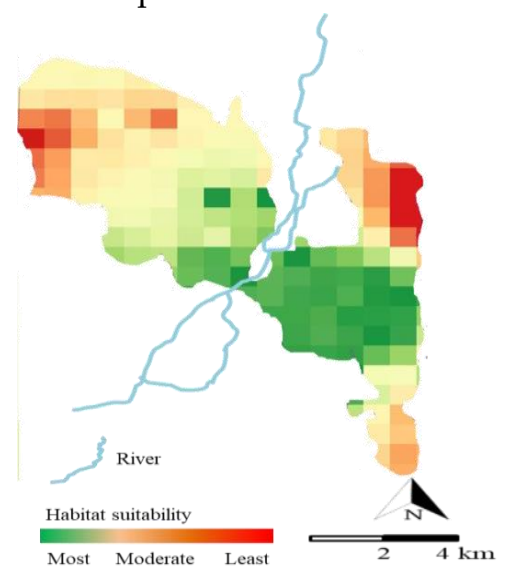


Figure 4. Habitat suitability of Hippopotamus sivalensis spp. in Kedung Brubus forest river basin, east Java in the late Pleistocene.

\section{Discussions}

The model developed in this study projected that the Pleistocene $H$. sivalensis spp. suitable habitats were centered near the river banks. This is in an agreement with the locations where most $H$. sivalensis spp. fossils have been found previously. H. sivalensis spp. in Java island was originated from the Asia continents with ranges from India to Africa under Hexaprotodon genus. Many literatures have reported the prehistoric hippos were found having proximity to the aquatic habitats. In east Africa, basin landscapes in the vicinity of Turkana were known having high abundance of prehistoric hippos (Arambour 1944, Arambour 1947, Coryndon 1977, Harris 1991). In Pakistan, 4 fossil localities of Hexaprotodon were found in Kas Chanatar basin that was surrounded by 2 rivers with width ranging from 50 to $100 \mathrm{~m}$ (Khan 2018). While in India, Hexaprotodon fossils were mostly found in rivers including Yamuna, Ravi, Narmada, and Godavari (Jukar 2019). The second explanations that can support the aquatic habitat proximity as presented in the model are related to the study by Brosserie (2005). H. sivalensis spp. was having eyes, ears, and nostrils placed high on the roof of the cranium which is this indicates H. sivalensis spp. already has proximity to the aquatic habitat (Zoric et al. 2018).

The habitat suitability model of Pleistocene $H$. sivalensis spp. was comparable to the Anthropocene hippos. Determinant factors that influence the habitat suitability of extant hippo species were incorporated in this model. Distance to the water body or in this study was a river, was one of the important factors determines the suitability of hippo habitats. Hippos are mammals that also have aquatic habitat besides their terrestrial habitat. A study by Buruso (2018) has shown comprehensively habitat suitability of hippos as in agreement with this study. Hippo prefers to live near the shallow water surrounded by grazing grass at the shore. This due to hippo's aquatic ecosystem requirement where hippos spend most of the time while forage pasture ashore (Eltringham 1999). Hippos were known aggregated on the vegetation covers near the river banks (Bogui et al. 2016). More hippo tracks per $\mathrm{km}^{2}$ were found within $500 \mathrm{~m}$ from the water body and numbers of hippo tracks were declining in the distance from the water body $>500 \mathrm{~m}$ (Eshuis 2011).

Elevation is another parameter should be considered in determine the suitable of hippo's habitats. The higher the elevation than the higher the abundances of hippo individuals. Hippo species was known climbing hills ranged $85-230 \mathrm{~m}$ to forage. In the Kedung Brubus, the elevation was ranging from $110 \mathrm{~m}$ to $387 \mathrm{~m}$. While only the hilly areas in the eastern parts that suitable since these areas were dominated by forest.

The closest Anthropocene hippo species to H. sivalensis spp. is Choeropsis liberiensis. This species differs to the common hippos due to its habitats in the forest and body mass. Compared to the $C$. liberiensis, $H$. sivalensis spp. has comparable weight and also habitat preferences. Weight ranges of C. liberiensis and H. sivalensis spp. are $230-280 \mathrm{~kg}$ (Taylor et al. 2013) and 160-272 kg (Weston 2009) respectively. Regarding the habitat preferences, in Kedung Brubus, fossils of $H$. sivalensis spp. were found in the forests near the rivers. While $C$. liberiensis, the extant species which has similar body mass to $H$. sivalensis spp, also prefers rainforest. Extant $C$. liberiensis are known living in the dense vegetation of the rainforest. Despite forest dweller, this species hide in swamps, wallows, or hollows under trees next to rivers during the day (Eshuis 2011). Hence, related to the extant species, H. sivalensis spp. suitable habitats were mostly in forest.

The model in this study informs that the factors that limit the habitat suitable were the elevation, distance to the river, and forest. In fact, this model is different to the Anthropocene hippo's habitat model has been developed recently. Most model developed by Bogui et al. (2016), Buruso (2018), and Eshuis (2011) incorporated anthropogenic disturbance factors in their analysis. However this factor was not realistic for analyzing the habitat suitability of $H$. sivalensis spp. This species was living during Pleistocene areas where anthropogenic disturbance factors were not significant as can be seen in Anthropocene era currently. 


\section{Conclusions}

H. sivalensis spp. is still having its closest relatives that still living during Anthropocene era nowadays. The habitat suitability model of extant hippo species then can be used and incorporated in developing suitable habitat of $H$. sivalensis spp. during Pleistocene.

\section{References}

Arambour C. 1944. Les Hippopotames fossiles d'Afrique. Comptes Rendus de l'Académie des Sciences Paris 218: 602-604.

Arambourg C. 1947. Mission Scientifique de l'Omo 1932-33, Tome I, Géologie - Anthropologie, fasc. 3. Paris: Editions du Muséum, 314-364.

Azis F. 2000. The Pleistocene Endemic Fauna of the Indonesian Archipelago. Tropics. 10(1): 135-143.

Boisserie J. 2005. The phylogeny and taxonomy of Hippopotamidae (Mammalia: Artiodactyla): a review based on morphology and cladistic analysis. Zoological Journal of the Linnean Society. 143: 1-26.

Bogui B, Koffi DA, Koné I, Ouattara K, Kouakou C, \& Gnagbo A. 2016. Distribution of Pygmy hippopotamus (Choeropsis liberiensis) in Taï National Park, Ivory Coast : Influences of natural and anthropogenic factors. International Journal of Research in Biosciences. 5. 27-35.

Buruso FH. 2018. Habitat suitability analysis for hippopotamus (H. amphibious) using GIS and remote sensing in Lake Tana and its environs, Ethiopia. Environ Syst Res 6, 6.

Coryndon SC. 1977. The taxonomy and nomenclature of the Hippopotamidae (Mammalia, Artiodactyla) and a description of two new fossil species. Proceedings of the Koninklijke Nederlandse

Akademie van Wetenschappen B80(2): 61-88.

Dietz AJ, Mohamed MA, Okeyo-Owuor JB. 2000. The hippopotamus: nothing but a nuisance? Hippo-

human conflicts in Lake Victoria area, Kenya. Thesis Environmental Geography Aenne W.C.H.M. Post, University of Amsterdam.

De Vos J, Sartono S, Sasmita HS, Sondaar PY. 1983. The pongo faunas from Java and Sumatra and their significance for biostratigraphical and paleoecological interpretation. Proc. Kon. Ned lletensch. B. 86 (4): 417Eltringham SK .1993. The common hippopotamus, Hippopotamus amphibius.

Eshuis H. 2011. Habitat preference and activity pattern of the pygmy hippopotamus analyzed by camera trapping and GIS.

Leinders M JJ, Aziz F, Sondaar PY, De Vos J. 1985. The age of hominid bearing deposit of Java: State of the art. Geologie en Mijnbouw. 4: 167-173.

Siswanto \& Noerwidi S. 2016. The faunal position of Patiayam site in the biostratigraphy of Java. SBA. 19(2): 149-166.

Sondaar, P.Y. (1984). Faunal evolution and the mammalian biostratigaphy of Java. Coun Forsch. Inst. Senckenberg. 69: 219 -235.

Sudijono. 1987. Status of the mammalian biostratigraphy of Java with special Sangiran area. In: 1tihara, M. \& T. Kamei., ed., Proc. of the First Inter. Coll. On reference to the Quarte. Strat. Of Asia Pacific Area. pp. 270-289. INQUA, Osaka.

Weston E. 2009. A new species of Hippopotamus Hexaprotodon lothagamensis (Mammalia:

Hippopotamidae) from the late Miocene of Kenya. Journal of Vertebrate Paleontology. 20. 177-185.

Harris JM. 1991. Family Hippopotamidae. In: Harris JM, ed. Koobi Fora research project 3. The fossil ungulates. Oxford: Clarendon Press, 31-85.

Jukar A, Patnaik R, Chauhan P, Li HC, Lin JP. 2019. The youngest occurrence of Hexaprotodon Falconer and Cautley, 1836 (Hippopotamidae, Mammalia) from South Asia with a discussion on its extinction. Quaternary International.

Kanga EM, Ogutu JO, Olff H, Santema P. 2011. Population trend and distribution of the vulnerable common hippopotamus Hippopotamus amphibius in the Mara region of Kenya. Fauna \& Flora International, Oryx.

Khan AM. 2018. Hexaprotodon (Mammalia: Hippopotamidae) from the Pinjor Formation of Bhimber, Azad Kashmir, Pakistan. Pakistan Journal of Zoology. 50.

Taylor LA, Rudd J, Hummel J, Clauss M, Schwitzer C. 2013. Weight loss in pygmy hippos (Choeropsis liberiensis). In: Steck, B. International Studbook for the Year 2012 - Pygmy Hippopotamus.

Basel: Zoo Basel. 20-25.

Wibowo A. 2020. Suitable Habitat Modeling of Prehistoric Antelope-like Bovid Duboisia santeng in Java Island in The Early Pleistocene. Preprints 2020090355. doi: 10.20944/preprints202009.0355.v1. Zorić Z, Lozance O, Marinković D, Blagojevic M, Nešić I, Demus N, Djordjevic M. 2018. Skull Bone 
Anatomy of the Young Common Hippopotamus (Hippopotamus amphibius). Acta Veterinaria. 68. 361-372. 